\title{
Issues of Gender Equality in the Workplace: The Case Study of Kazakhstan
}

Dauletbai U. Ryskaliyev, ${ }^{+*}$ Sabyrzhan M. Zhapakov, ${ }^{\uparrow}$ Nurlan Apakhayev, ${ }^{*}$ Zhanar Moldakhmetova, ${ }^{i}$ Yermek A. Buribayev, '́ and Zhanna A. Khamzina'

\section{Abstract}

Family circumstances and gender equality are the factors which influence the formation of labour legislation and state policy in the sphere of wage labour. That is why this research analyses the issues of gender equality in workplace relations. The study uses unity and a differentiation method of wage labour employment regulation. This method allowed us to determine the specifics of workplace relations, which involve women and people with family responsibilities. It was established that the optimal legal regulation of women's labour and labour of people with family responsibilities must be directed at achieving gender equality in the workplace and creating the conditions under which women and other people would be able to combine work and family responsibilities. The creation of a supportive environment for workplace relations of the specified categories of workers must be implemented through both internal and global regulations. The activities on both levels are mutually reinforcing in nature. The article, having analysed the Labour Code of the Republic of Kazakhstan and international labour standards, submits suggestions about improvement of labour laws, draws conclusions about the necessity of legal protection for women and people with family responsibilities as well as the elimination of discriminating factors in relations regulated by labour laws.

Keywords: Wage Labour, Gender, Women's Labour, Social and Labour Rights of a Person with Family Responsibilities, Discrimination, Kazakhstan

\footnotetext{
${ }^{+}$Department of Civil Law and Civil Process, Labour Law; Al-Farabi Kazakh National University, 050000, 71 Al-Farabi Ave., Almaty, Republic of Kazakhstan

${ }^{*}$ Corresponding Author, Email: r.daulet@mail.ru

ÎSchool of Applied Sciences, Narxoz University, 050010, 55 Zhandosov Str., Almaty, Republic of Kazakhstan

$¥$ Department of History of Kazakhstan and Law, Kainar Academy, 050000, 7A Satpaev Str., Almaty, Republic of Kazakhstan

' Department of State and Civil Law Disciplines, Abai Kazakh National Pedagogical University, 050010, 13 Dostyk Ave., Almaty, Republic of Kazakhstan

(C) 2019 Ryskaliyev et al. This is an Open Access article distributed under the terms of the Creative Commons Attribution License (http://creativecommons.org/licenses/by/2.0), which permits unrestricted use, distribution, and reproduction in any medium, provided the original work is properly cited.
} 


\section{Introduction}

Active involvement of women in economic and public life can be determined in terms of factors which have an influence on the dynamics of social policy (Atanelishvili \& Silagadze, 2018; Silagadze, 2018). The Labour Code of the Republic of Kazakhstan defines people with family responsibilities and women as subjects provided with social and labour guarantees, compensations and allowances, whose legal status bears a differentiation of labour laws. Modern law contains the rules that enable women during gestation to keep their employment and during puerperium to maintain their employment without consequence for a child and his upbringing (Vinichenko et al., 2016).

Alongside this, the issue of discrimination in the workforce is relevant to the reality of economic relations in Kazakhstan. The most widespread form of discrimination is sexual discrimination as women of any age, with and without children, have by far fewer chances to receive a job offer if their competitor is a man; even if the latter is less qualified or has less experience(Kirillov et al., 2017; Maria-Abalos, 2016; Jain et al., 2018). Employers tend to downsize their workforce or the number of employees by solely making women redundant. Workers of pre-retirement and retirement age suffer from discriminatory prejudices (Kirillov et al., 2017; Tandzegolskienè \& Jurgilè, 2015). There exists pay discrimination for the labour of equal qualification regarding women, minorities, local population and migrant workers while the latter is not always discriminated against. A so-called "professional segregation" has appeared in the society, and it demonstrates a sharp division of industries into"male" and "female", "traditional labour of local population" and "migrant labour". "Occupational gender segregation has generally been assumed to be a structure of gender inequality in the labour market; high levels of segregation are equated with high levels of gender inequality in the society" (Blackburn et al., 2000: 122). In addition, there are no stringent anti-sexual harassment laws for prevention of sexual harassment at the workplace in
Kazakhstan (Sexual Harassment at Workplace: Legal and Policy Challenges In the Republic Of Kazakhstan, 2017). In this context, it is worth noting that in October 2017, the \#MeToo movement was launched in the social media because of the rampant prevalence of sexual assaults at the workplace. It started with a series of allegation against the Hollywood icon Harvey Weinstein by a number of Hollywood actors. An American social activist, Tarana Burke first used the phrase 'me too' in 2006 to help victims of sexual harassment; in 2017 the phrase was taken to the Twitter by the American actor Alyssa Milano, from which the movement gained popularity (Bhattacharyya, 2018; see also, Singh \& Kumar, 2019; Tripathy, 2018). According to the UN Women Central Asia in Kazakhstan too, this movement has been gaining ground together with the launch of a similar local movement\#НемолчиKZ hashtag ("don't be silent") (Abdurasulov, 2018; UN Women Central Asia, 2018). Despite these small developmental steps, sexual assaults against women, both at the workplace and public areas continues to be widespread (Abdurasulov, 2018; Abramova et al., 2018).

Notwithstanding, as a significant step towards eradication of discrimination between men and women in the workforce, by 2013 , the concept of family and gender policies in the Republic of Kazakhstan was enacted by a Presidential Decree of 06 December 2016 No. 384 where the following relevant issues are listed-currently, among 411 active political government personnel, only 40 are women that is only $9.7 \%$, a decrease of $11 \%$ in 2005 . However, in the OECD countries, in 2015, women, on average, held $29.3 \%$ of ministerial positions. Alongside this, insufficient representation of women in senior ranks of the corporate sector in Kazakhstan is still evident. According to the World Bank, women hold top leadership posts only in $9.8 \%$ of big corporations (Den Dulk et al., 1996) In the list of Fortune of 2018 , only 24 women $(4,8 \%)$ have been heads of a company. Women constitute less than a quarter (24\%) of leadership positions in the world. In 2017, women on leadership 
position were $22 \%$ in the USA, $15 \%$ in Europe and only 4\% in Asia (Quick Take: Women in the Workforce - Global, 2018). In major global companies, women comprise approximately $41 \%$ of the total number of employees, but only 19\% hold senior leadership positions and 12\% hold management positions (Atanelishvili, \& Silagadze, 2018).

There has been practically no shift in industrial gender segregation. Women still comprise more than $70 \%$ of wage labour in healthcare, education and social services, while the representation of women if financial and governmental sectors composes a bit more than a half (Kirillov et al., 2017). Historically, these sectors are less profitable in comparison to "male-dominated sectors", such as construction, oil and gas sector, extractive industries and transportation.

So, for achieving a set objective, the authors studied the following issues:

- analysis of the gender equality development in developed countries and developing countries;

- factors that influence women's work are studied;

- Labour legislation of the Republic of Kazakhstan is analysed. The features of social labour rights and duties are revealed;

- new Labor Code of the Republic of Kazakhstan is analysed;

- particularities of employees with special social status are revealed.

The following section dedicates to review of the literature to tease out the gap this research aims to address.

\section{Literature Review}

Issues of discrimination towards women, people with family responsibilities are relevant today, despite huge progress in this sphere, positive development of national law systems and universal international standards. The conclusion expressed in the work of E. Johnstone (1968), half a century ago are still observed as valid for current times and asserts that while discrimination and built-in prejudice against women in employment have been reducing in most parts of the world, in law and practice, many economic, social, and cultural factors and attitudes still place women at a disadvantage in the world of work and restrict their contribution unnecessarily and, in many cases, unfairly (Ushakov et al., 2017). The International Labour Organization (ILO) can help promote equal rights and opportunities for women and ensure them the social protection they need about their special role of maternity and motherhood.

The Soviet legislation contained provisions that guaranteed equal opportunities for women and men, including the sphere of labour and economy. However, during the Soviet period, there was a tendency for women to engage in "female" professions with more time devoted to upbringing children. Women were free to return to their former jobs because the stateguaranteed protection against unemployment. At present, the economic activity of women in the region continues to be rather high: 80 women who work account for by every 100 men (Busetti \& Dente, 2018).

L. S. Rzhanitsyna rightly notes that it is impossible to speak about the real development of humankind without taking into account a gender factor. Moreover, women in almost all countries make up half or even more of the population. Gender inequality persisted in society due to stereotyped views of men and women. Besides this, in its turn, is projected on labour relations (Rzhanitsyna, 2015).

Kasima Takashi, who heads the Association for the Development of Women's Employment, emphasises that in Japan, the basic principle of work organising is still the system of full-time employment of men, while women do not have the conditions to continue working after the maternity leave. In August 2015, a law was promulgated, the main aim of which was to contribute to the promotion of women's professional activity (Naohisy, 2018). Women in the USA work in all sectors of the economy, in large and small business, making a huge contribution to the development and prosperity 
of the country. The influence growth of women in the USA policy is due to the increase of their social activity and level of education (Liu et al., 2018).

The Law on Gender Equality exists in the countries of North Europe (Scandinavian model). Women's representation in the governing bodies is also crucial in countries such as the Netherlands, Ireland and Germany. In Canada, there are special authorised state bodies: the Ministry of Women's Affairs and the Department of Gender Equality under the Canadian International Development Agency. The USA in 1963 - 1964 adopts the laws on equal pay and prohibition of discrimination (Pierotti et al., 2018). In 2017, gender inequality worsened in 82 countries out of the 142. In Kenya, Brazil, Japan and India the number of women, who occupied decision-making positions in the governing bodies, reduced, and in Mexico, South Africa and Spain, the rates of providing economic opportunities for women on an equal footing with men declined (Landay \& Oshkosh, 2019).

Despite the overall gap widening, the situation has improved in some countries. For example, in France, the number of women in Parliament has significantly increased after the elections, and in Canada, the number of Women Ministers increased. Iceland remains a leader in gender equality. The USA dropped four lines to 49th place in the rating, in particular, due to the reduction of the number of women in Ministerial positions. However, an equality indicator of political representation in the USA is at its lowest level since 2007 . Three leaders of the rating are the countries of Northern Europe, but the top-10 also includes non-European countries such as Rwanda (4th place), Nicaragua (6th place) and the Philippines (10th place).

It was saddening to witness a 2018 report published by the World Economic Forum stating that it would take at least 100 years for our planet to completely overcome gender discrimination (Peters, 2017; Landay \& Oshkosh, 2019). However, in the current, situation, gender equality is observed in Iceland. The overall equality index in this country is $87.8 \%$, it becomes a leader of the rating of the World
Economic Forum for the ninth year consecutive. Iceland is the only country where women's political participation has exceeded $70 \%$. The top five are -Norway, where the overall level of equality was $83 \%$, Finland (82.3\%), Rwanda (82.2 \%) and Sweden (81.6 \%).

Analysis of separate issues of regulatory support of gender equality in the workforce is reflected in special scientific studies that focus on the employment of migrants (Bailey \& Cooke, 1998; Raghuram, 2004), balance between work and family responsibilities (Fredriksen, 1993; Parasuraman \& Simmers, 2001), comparative research into ensuring social and labour rights of women, people with family responsibilities (Orloff, 1993) and application of atypical work (Kalleberg, 2009).

From the latest published works in the postSoviet space, the study by M. Burbyka et al. (2017) proves to be quite interesting; it states about investigation of the problems arising in the process of women's employment and give recommendations for overcoming discrimination against women in the labour market (Akhmetshin et al., 2018).

\section{Characteristics of Women's Labour}

Even though the average salary of women who work in comparison to that of men increased from $62 \%$ in 2006 to $67 \%$ in 2015, the gap between the average salary of men and women remains 33\% (Burbyka et al., 2017). Involvement of women's work in innovative, infrastructural and high-technology projects and programmes is at a very low level. According to the national statistics, every third rural woman in Kazakhstan is self-employed and has an income from subsistence farming, a part of which goes into personal consumption (Official statistical information, 2019).

The Concept of state policy for the advancement of women in the Republic of Kazakhstan supposes the creation of the conditions for ensuring equal employment for men and women; notably, the following measures will be implemented. The evaluation of the population's economic activity will be compiled bearing in mind gender specifics of individual 
regions and production sectors as well as the poverty monitoring data. Gender-sensitive indicators that measure unaccounted domestic labour, informal employment, home-based work and paid domestic labour will be included in the system of national accounts. Expanding economic opportunity for women will be supported through the facilitation of employment and entrepreneurship, including the economic sectors which are traditionally managed by men. Taking into account gender aspect, the labour regulation and legislation protection will be enhanced; working conditions will be improved, the possibilities of implementing and expanding flexible forms of employment will be examined.

The factors that influence the existence of a sufficiently long period of withdrawal from economic, labour and public life are childbirth and her further support and upbringing; specified circumstances are in the majority of cases "a hindrance" on the way to the realisation of their ability for labour and independent economic activity. Alongside the outlined, modern forms of family life allow changes in "traditional" division of responsibilities in the family and transfer of childcare responsibilities to men or other family members.

Outlined considerations lead to the conclusion about the necessity of finding the optimal way of adhering to everyone's interest in the formation of legislation and implementation of national social policy that takes into account all circumstances and consequences of the approved decisions.

\section{Analysis of Labour Laws Differentiation}

The most important feature of labour legislation is its unity and differentiation manifesting in the following. The current combination of labour legislation laws and guarantees, on the one hand, expands its scope overall workers employed in the Republic, on all its territory, applicable to the level of solidifying universal social and labour rights, guarantees and responsibilities. On the other hand, through various factors like being a minor, specific working condition, a special ecological status of the territory where the work is conducted, a specific sphere of economic relations or a functioning area of state apparatus, there exist legal rules that establish unique, specific working conditions for affected employees(Khamzin et al., 2015).. The design of this labour legislation is expressed by, in one respect, establishing universal rights, employees' and employers' responsibilities, an order of contract conclusion, reasons for contract's termination in labour legislation, and in another respect, emphasising rules that consolidate labour regulation of isolated categories of employees (Kirillov et al., 2017). The differentiation of labour legislation currently exists in labour legislation on the following grounds: depending on sex and age characteristics of employees, their health status, family responsibilities; depending on the nature of labour and work conditions; depending on the territory of labour.

The enhancement of the differentiation is one of the modern trends of labour law development arising from the variety of forms of organised labour in the society and the need to adjust general rules to specific categories of employees (Golovina, 2014). The analysis was based not only on the research of internal law of the Republic of Kazakhstan but also on the universal international standards of wage labour, secured in the International Labour Organization (the ILO) Conventions and Recommendations. The study of special labour legislation, which governs labour of women and people with family responsibilities, was conducted from the position of finding a balance between interests of employers, employees and the state in modernising labour market and protection of social well-being and stability in society.

Actual research should be perceived as an establishment and a consolidation of a specific scientific level of research into labour laws achieved in Kazakhstan. It is worth mentioning here that this research indeed is a continuation of an authors' research work in the field of wage labour (Mukhamadiyeva et al., 2017; Ibraev et al., 2017; Khamzin et al., 2015).

\section{Evaluation of Labour Rights Discrimination}

Discrimination in the workplace can occur on the grounds of sex, age, afflictions, race, nationality, 
language, property, social and professional status, residence, religious or political beliefs, family or class affiliation and public organisation. Despite the approval of numerous international documents ensuring labour rights, women and people with family responsibilities still suffer from discrimination in the workplace. Only through achieving real, factual gender equality, spreading the awareness about the role and rights of women in the society, signing international conventions, governmental and public control over the implementation of commitments, it is possible to solve this problem. Awareness about the need to ensure gender equality, as well as a multifaceted approach through the proper fulfilment of international conventions, agreements and decisions of the international organisations using a sophisticated system of mechanisms, allows highly-developed countries to ensure social and labour rights of women and people with family responsibilities.

Behind the principle of forbidding discrimination in the workplace is the provision of equal rights and opportunities to workers:

- opportunity to obtain employment and be an employee in the organisation under any form of ownership;

- opportunity to obtain suitable employment depending on the speciality and qualification without discrimination;

- opportunity to demand safe working conditions;

- opportunity to receive corresponding guarantees, compensation from the employer in case of dismissal; to receive information about employment without discrimination from an official state employment agency;

- opportunity to demand the restoration of violated labour rights. The principle of prohibiting discrimination in the workplace covers all subjects of labour laws and is implemented in all its institutions.

Based on this research, authors have outlined the following factors that lower the level of labour guarantees for women:
- high level of self-employed population among women;

- restricting employment for women over the age of 40 ;

- implicit wage discrimination for equal labour;

- low level of social allowance and maternity benefits;

- increase of education among women coupled with a low number of jobs occupied by women in high-paid spheres of work;

- absence of guarantees for dismissal due to age, marital status or other discriminatory reasons;

- a higher level of poverty among women in comparison to men.

In our view, establishing additional legislative guarantees in the workplace for people with family responsibilities is aimed at creating equal opportunities for them alongside people who are not burdened with such responsibilities while exercising their right for labour, ensuring working conditions that allow them to combine professional and family responsibilities. With these goals in mind, the Labour Code of the Republic of Kazakhstan should provide a rule that obliges an employer during recruitment to prioritise people with family responsibilities, if they have equal qualifications with other applicants, alongside civilians with quotas for jobs following established procedures. On the other hand, an employer does not have to suffer significant economic costs when providing social and labour guarantees to people with family responsibilities; for this purpose, there should be established tax benefits for employers that utilise the labour of such workers. It is possible to apply similar conditions of tax benefits in the form of the tax rates reduction for subjects that utilise the labour of handicapped, meaning there should be an incentive for the employer to utilise the labour of the most socially vulnerable categories of workers. Social responsibility of business is an essential component when dividing the burden of implementation of social 
policy between a business community and the state. However, the characteristics of social and labour rights depend on them being secured and ensured by the state mechanism.

The main aim of the legislation is to find an optimal variant between additional guarantees that are established for those who need them and their competitive ability on the job market. It is assumed that factual exclusion of people with family responsibilities from the Labour Code as a category of workers having a special privileged social and labour status does not contribute to productive employment of these individuals and does not guarantee their nondiscrimination in the workplace.

\section{Characteristics of New Labour Legislation of the Republic of Kazakhstan}

Ensuring gender equality remains a sensitive topic in the reality of labour relations in Kazakhstan. In 2015-2016, the reform on regulating the sphere of wage labour was implemented, and the new Labour Code was adopted. One of the goals of the legislative update was to change the characteristics of normative regulation, reasons for creation, modification and termination of labour relations with one of the most vulnerable categories of workers - people with family responsibilities and women (The new Labor Code of the Republic of Kazakhstan will determine the boundaries of state interference in labor relations, 2015).

When the new Labour Code was being adopted, one chapter was left out - "Labour of Women and People with Family Responsibilities Regulation Specifics". The removal of the whole chapter from the Labour Code which regulated the labour of people with the weakest competitive ability in the job market reflects one possible understanding of labour relations liberalisation from the legislator's point of view. Meanwhile, the Labour Code has significantly decreased the level of social labour rights of the listed categories of workers regarding the purpose of the guarantees in the previous Labour Code of the Republic of Kazakhstan.

Traditionally, in labour legislation, individuals with family responsibilities are recognised as subjects whose legal status is differentiation in labour legislation that provides social and labour guarantees, compensation and allowance. Labour legislation of the Republic of Kazakhstan began, for the first time since 2007, incorporating childcare leave upon reaching three years age mark at the choice of parents mother, father, grandparents, or any other relative or guardian who actually raises a child in question. It is worth noting that the specified legal norms are factually inactive in Kazakhstan. Men rarely use this privilege.

One of legislators' unresolved problem is the absence of a legal definition of workers with family responsibilities: who can be included in this category and regarding whose status working conditions should be differentiated are still open questions. It is unclear which attributes designate an individual as a worker with family responsibilities. In our view, the following circumstance can designate a worker with family responsibilities: an employee that has a responsibility to educate and nurture a child in accordance with the family or any other legislation (parent, adoptive parent or individual with the rights and responsibilities of a guardian); any other child's relative caregiver in cases directly prescribed by law; a worker with responsibilities regarding his/her family members who obviously needs care or support. The designation of individuals, who raise a child without a mother, can be granted to a father, an individual with the rights and responsibilities of a minor's guardian, if a mother is dead, deprived of her parental rights, limited in her parental rights, declared missing or disabled (partially disabled), cannot raise and support a child for medical reasons, serves a sentence in detention facilities, avoids raising a child or protecting his/her rights and interests, has refused to collect his/her child from an educational facility, medical facility, facility providing social services or a similar facility, in other situations. It is assumed that other individuals can be designated as having family responsibilities or raising a child without a mother, taking into consideration particular circumstances that demonstrate their fulfilling responsibilities of public importance. 
According to labour legislation, discrimination in the workplace should be understood as a difference, exclusion or a preference aimed at elimination or violation of equal opportunity in realisation of labour rights and freedoms or obtainment of any benefits on account of any circumstances that are not connected to professional qualities, besides differences, exclusions, preferences or limitations, established by the Republic of Kazakhstan laws for the relevant types of employment or that stems from state's special concern about people in need of social and legal protection.

\section{Characteristics of Workers with a Special Social Status}

The new labour legislation of Kazakhstan, which took effect in 2016, has significantly decreased the level of social and labour guarantees for women, children and people with family responsibilities, regarding forms and methods of workers' rights protection. It excludes women with children aged 3 to 7 and other individuals who raise children of this age without a mother, and workers who provide care for sick family members that, according to a medical report, need long-term care, from the category of workers with a special social status.

Moreover, the limitation of social and labour rights of workers with family responsibilities does not correspond with the content and level of international commitments, adopted when ratifying the ILO Convention No. 156 concerning Equal Opportunities and Equal Treatment for Men and Women Workers: Workers with Family Responsibilities (under the Law of the Republic of Kazakhstan of 16 November 2012 No. 50-V (The Law of the Republic of Kazakhstan, 2012). Under universal norms, with which the Republic of Kazakhstan has agreed, the Convention No. 156 applies to men and women workers with family responsibilities in relation to their dependent children where such responsibilities restrict their possibilities of preparing for, entering, participating in or advancing in economic activity; it also applies to men and women workers with responsibilities in relation to other members of their immediate family who clearly need their care or support, where such responsibilities restrict their possibilities of preparing for, entering, participating in or advancing in economic activity (Convention No 156, 1983).

Provision of actual equality of treatment and opportunities for men and women workers relies on one of the goals of the state policy where Convention No. 156 has been ratified offers people with family responsibilities, working or desiring to work, the possibility to exercise their right for it without being subject to discrimination and to combine professional and family responsibilities to the extent possible.

According to international act, every state defines "dependent child" and "other member of the immediate family who clearly needs care or support" (Pierotti et al., 2018: 542) independently through legislation or any other method of legal regulation, establish special measures to ensure social and labour rights of workers with family responsibilities. Requirements of the Convention No. 156 may be applied by stages if necessary, account being taken of national conditions. Gradual implementation of measures securing the provisions of the Convention No. 156, a requirement to implement respective dedicated state policy, in our view, suggests a progressive development of social and labour rights of workers with family responsibilities using, appropriate changes in the legislation. However, the level of guarantees in the Labour Code of 2016 is the evidence of regression concerning the status of the specified participants of labour relations.

Considering the preceding conclusions, a question arises: how does the regression status of social and labour rights of women, people with family responsibilities, corresponds with the liberalisation of the labour legislation as a significant dedicated indicator of development and adoption of the Labour Code in 2016?

New Labour Code was developed as part of a national plan - 100 concrete steps towards the realisation of five institutional reforms of Nursultan Nazarbayev, Head of State, where step 83: the liberalisation of labour relations (Van et al., 2017). Development of the new 
Labour Code based on the undertaken informational campaign about adopting and clarifying the Labour Code, its creator viewed liberalisation of labour as an enhancement of the role of a collective contractual regulation of labour relations; expansion of the mechanism of a flexible regulation of wage labour; optimal combination of state and contractual regulation of labour relations. "It is suggested that the dominant theme of labour law policy has become the enhancement of the competitiveness of business, which, at its core, requires the facilitation and stabilization of flexible employment relations" (Collins, 2001: 23).

In the author's opinion, liberalisation of the labour legislation involves advancing the latter to the real situation and thereby forming prerequisites for its abidance. Emphasis must be placed on creating and expanding the mechanisms of self-regulation on the job market under an appropriate level of state regulation.

Deterioration of status of social and labour rights of people with family responsibilities, women, according to the creator of the new Labour Code, constitutes measures aimed at stimulating the job creation for the specified categories of workers. It is worth noting that the cancellation or limitation of social and labour guarantees for women, children, people with family responsibilities, are advocated for because strict mechanisms of ensuring the specified guarantees damage the rights of workers with family responsibilities, especially women. Employer avoids hiring them.

It is believed that juxtapositions of a presented and widespread position constitute the following: Individuals with family responsibilities, including women, constitute at least $60-70 \%$ of the total number of contract workers, as well as of the unemployed population. As a result, most workers (men and women) are workers with family responsibilities that are accountable for their family and children to each other and society. This significant part of the population, which combines family responsibilities and work, must be provided with the ability to exercise their right for free choice of employment without being subject to discrimination. Elimination of the widespread latent discrimination towards women, people with responsibilities, must become the development goal of the labour legislation. The Labour Code has not in any way solved this issue: declaration of prohibiting discrimination, apparently, does not create equal opportunities in exercising rights and freedoms in the workplace.

\section{Conclusion}

The system of guarantees for women workers, people with family responsibilities, supported by real mechanisms of their legal enforcement, meaning accountability for their violation, was installed into the Labour Code. However, such kind of accountability is absent in some cases. For example, Article 6, paragraph 4 of the Labour Code secures the right to appeal to a court or another authority in accordance with the law for individuals who believe they have suffered discrimination in the workplace. Nonetheless, the legislation does not determine the procedure of appeal for judicial protection on the basis of discrimination in the workplace, the procedure of shielding from discriminatory actions (inaction) is not legally established, and, moreover, actions of discriminatory nature usually inflict both material and emotional damage. The outlined illustrates the presence of defects in legal protection of violated rights procedures exhibiting elements of corruption.

The article 90 of the Labour Code of 5th July 2014 No. 235-V of the Code of Administrative Offences of the Republic of Kazakhstan secures a limited definition of discrimination in the workplace that possesses the elements of an administrative offence. Such offences include Allowance of discrimination in the workplace expressed as a violation of the right of workers for equal pay for equal labour. All other possible manifestations of discrimination that are not covered by legal liability. Flawed enforcement of legal liability for discriminatory offences in the workplace requires further correction, which may motivate the advancement of the Institute of social and labour rights of women, people with family responsibilities. The labour 
legislation of the Republic of Kazakhstan is defective and must be reformed in order not only to declare but defend the rights of women following current reality and fluctuations in the job market.

The study contributes to the research of combating gender discrimination on the job market of Kazakhstan. Discrimination against women on this stage is one of the most common forms of gender inequality. This research has identified several gaps in labour legislation. It has been determined how current legislation, which regulates labour relations, complies with the policy of equal rights and opportunities for men and women. Recommendations were developed, directed at changing legal norms to prevent gender discriminations, which have the purpose of solving existing gender issues in the workplace.

\section{References}

Abdurasulov, A. (2018, 18 March).Speaking up about rape in conservative Kazakhstan. $B B C$ News. Retrieved on 20 March 2019 from, https://www.bbc.co.uk/news/world-asia43247005.

Abramova, I. E., Ageeva, N. A., Shapoval, G. N., Lysenko, K. N., Samofalova, M. V. (2018). Russia-India: Indian students' adaptation in Russian universities in the context of the dialogue of civilizations and cultures. Periodico Tche Quimica, 15(30), 87-94.

Akhmetshin, E. M., Vasyaycheva, V. A., Sakhabieva, G. A., Ivanenko, L. V., \& Kulmetev, R. I. (2018). Key determinants of labor market development of Samara region. In Proceedings of the 31st International Business Information Management Association Conference Innovation Management and Education Excellence through Vision 2020, pp. 3914-3923.

Atanelishvili, T., \& Silagadze, A. (2018).

Formation of economic views in the ancient era. Bulletin of the Georgian National Academy of Sciences, 2(1), 191-196.

Bailey, A. J., \& Cooke, T. J. (1998). Family migration and employment: the importance of migration history and gender. International Regional Science Review, 21(2), 99-118.

Bhattacharyya, R. (2018, March). \#MeToo Movement: An Awareness Campaign. International Journal of Innovation, Creativity and Change 3(4): 1-12. Retrieved on 24 October 2018 from,

http://www.ijicc.net/images/Mrach18_spec_ed ition/battacharyarra_March18.pdf

Blackburn, R. M., Jarman, J., \& Brooks, B. (2000). The puzzle of gender segregation and inequality: A cross-national analysis. European Sociological Review, 16(2), 119-135.

Burbyka, M., Klochko, A., Logvinenko, M., \& Gorbachova, K. (2017). Separate aspects of legal regulation of women's labour rights". International Journal of Law and Management, 59(2), 271-

283, https://doi.org/10.1108/IJLMA-02-20160021.

Busetti, S., \& Dente, B. (2018). Designing multiactor implementation: A mechanism-based approach. Public Policy and Administration, 33(1), 46-65.

Collins, H. (2001). Regulating the employment relation for competitiveness. Industrial Law Journal, 30(1), 17-48.

Convention No 156. (1983, 11 August) The Convention on Equal Treatment and Equal Opportunities for Men and Women Workers: Workers with Family Responsibilities. Retrieved on 20 April 2019 from,

http://www.ilo.org/wcmsp5/groups/public/--ed_norm/---

normes/documents/normativeinstrument/wcm s_c156_ru.htm

Den Dulk, L., van Doorne-Huiskes, A., \&

Schippers, J. (1996). Work-family arrangements and gender inequality in Europe. Women in Management Review, 11(5), 25-35.

https://doi.org/10.1108/09649429610122627

Fredriksen, K. I. (1993). The provision of informal adult care: The impact of family and 
employment role responsibilities. Berkeley: University of California.

Golovina, S. Y. (2014). Enhancing the Diff erentiation of the Russian Labour Legislation. Russian Law: Theory and Practice, 2, 86-94.

Ibraev, Z. G., Yerkebaeva, N. A., Mirzakulova, B. A., Nazarkulova, L. T., Buribayev, Y. A., \& Khamzina, Z. A. (2017). Social rights, family and child guarantees in the context of the implementation of a new social course in the Republic of Kazakhstan. Journal of Legal, Ethical and Regulatory Issues, 20(1), 1544-0044-20-1128.

Jain, P., Sodha, D., \& Jain, M.P. (2018). Gender Differences and Political Deliberations on Social Media. Media Watch, 9(3), 465-471

Johnstone, E. (1968). Women in economic life: Rights and opportunities. The Annals of the American Academy of Political and Social Science, 375(1), 102-114.

Kalleberg, A. L. (2009). Precarious work, insecure workers: Employment relations in transition. American Sociological Review, 74(1), 1-22.

Khamzin, A. Sh., Khamzina, Zh. A., \& Buribayev, Y. A. (2015). The decent work programme of Kazakhstan: Social and labor rights protection from an institutional aspect of international law. Journal of East Asia and International Law, 8(2), 539-540.

Kirillov, A. V., Ushakov, D. S., Vinichenko, M. V., Makuchkin, S. A., \& Melnichuk, A. V. (2017). Career opportunities for the management's personnel reserve. Eurasian Journal of Analytical Chemistry, 12(5b), 723-733.

Landay, K., \& Oshkosh, W. (2019). Applicant Gender and Recruiter and Organizational characteristics. Gender in Management, 34(1), 2-18.

Liu, A. H., Shair-Rosenfield, S., \& Vance, L. R. (2018). Zsombor Csata. Linguistic Origins of Gender Equality and Women's Rights. Gender and Society, 32(1), 82-108.

Maria-Abalos, C. F. L. S. (2016). Social Mobilization in the Net Space: Re-constructed
Communication, Identity and Power. Media Watch, 7(1), 5-18

Mukhamadiyeva, G. N., Kussainova, A. K., Baisalova, G. T., Apakhayev, N., Khamzina, Z. A., \& Buribayev, Y. A. (2017). Labour law of the modern Kazakhstan. Journal of Legal, Ethical and Regulatory Issues, 20(1), 1544-0044-20-1129.

Naohisy, M. (2018, 19 May). Modern View of Japan. Retrieved on 15 April 2019 from, https://www.nippon.com/ru/

Official statistical information. (2019, 23 February). Retrieved on 14 April 2019 from, http://stat.gov.kz/faces/

Orloff, A. (1993). Gender and the Social Rights of Citizenship: The Comparative Analysis of Gender Relations and Welfare States. American Sociological Review, 58(3), 303-328.

Parasuraman, S., \& Simmers, C. A., (2001). Type of employment, work-family conflict and well being: a comparative study. Journal of Organizational Behavior, 22(5), 551-568.

Peters, M. A. (2017). Gender Equality. Encyclopedia of Educational Philosophy and Theory. Springer: Singapore.

Pierotti, R. S., Lake, M., \& Lewis, C., (2018). Equality on His Terms: Doing and Undoing Gender through Men's Discussion Groups. Gender and Society, 32(4), 540-562.

Quick Take: Women in the Workforce - Global. (2018, 31 October). Retrieved on 20 March 2019 from, https://www.catalyst.org/research/women-inthe-workforce-global/.

Raghuram, P. (2004). The difference that skills make: gender, family migration strategies and regulated labour markets. Journal of Ethnic and Migration Studies, 30(2), 303-321.

Rzhanitsyna, L. S., (2015). The conception of women's employment. Moscow: Institute for Economics at the Russian Academy of Science.

Sexual Harassment at Workplace: Legal and Policy Challenges In the Republic of Kazakhstan (2017, July). UN Women. Retrieved 20 March 2019 from, http://www2.unwomen.org/- 
/media/field\%20office\%20eca/attachments/pu blications/country/mco-

kazakhstan/2017\%20kp\%20on\%20sexual\%20ha rassment\%20final\%20eng.pdf?la=en $\& v s=4532$

Silagadze, A. (2018). Some aspects of economic ideas in Shota Rustaveli's "the knight in the panther skin". Bulletin of the Georgian National Academy of Sciences, 12(1), 161-167.

Singh, S., \& Kumar, A. (2019). Sexual Violence in Indian Public Sphere: Counter-public Creation and Deferral. Journal Space and Culture, India, 6(5), 8-28.

https://doi.org/10.20896/saci.v6i5.317

Tandzegolskienè, I., \& Jurgilè, V. (2015). Work and family reconciliation: issues and policy. Journal of International Scientific Publications: Educational Alternatives, 13, 240-252.

The Law of the Republic of Kazakhstan. (2012, 16 November). On the ratification of the Convention on Equal Treatment and Equal Opportunities for male and female workers: workers with family responsibilities (Convention No. 156). Retrieved on 21 April 2019, from https://online.zakon.kz/Document/?doc_id=31 292466

The new Labor Code of the Republic of Kazakhstan will determine the boundaries of state interference in labor relations. (2015, 03 September). Retrieved on 21 April 2019, from https://www.kt.kz/rus/politics/novij_trudovoj_ kodeks_rk_opredelit_granici_gosudarstvennogo _vmeshateljstva_v_trudovie_otnoshenija_1153 609701.html

Tripathy, M. (2018). Breaking the Code of Gender Barrier to Leverage the Position of Women in Indian Workplaces. Journal Space and Culture, India, 6(3), 180-193.

https://doi.org/10.20896/saci.v6i3.328

UN Women Central Asia. (2018, 24 May).

Retrieved on 20 March 2019 from, https://twitter.com/unwomenctrlasia/status/99 9585161829408769

Ushakov, D., Elokhova, I., \& Kozonogova, E. (2017). Post industrialization prospects in the dynamics of socioeconomic transformations: Cluster approach. International Journal of Ecological Economics and Statistics, 38(2), 2332.

Van, H. T., Huu, A. T., \& Ushakov, D. (2017). Liberal reforms and economic growth: Current issues and interrelations. Journal of International Studies, 10(4), 109-118.

Vinichenko, M. V., Makushkin, S. A., Melnichuk, A. V., Frolova, E. V., \& Kurbakova, S. N. (2016). Student employment during college studies and after career start. International Review of Management and Marketing, 6(S5), 23-29. 